\title{
School Libraries on the Agenda: An IFLA / IASL Project
}

\author{
Dianne Oberg \\ University of Alberta, Canada doberg@ualberta.ca \\ Barbara Schultz-Jones \\ University of North Texas, USA barbara.schultz-jones@unt.edu \\ Lourense Das \\ Meles Meles SMD, Netherlands iasl@meles.nl
}

\begin{abstract}
School library advocacy is a concern worldwide. Getting school libraries on the agenda for consideration by a school staff, or a ministry of education, or a library association is often a challenge. This paper describes the process being undertaken by two international school library groups to develop school library advocacy training materials which will be freely shared through the Online Learning Platform of the International Association of Library Associations and Institutions (IFLA). The two-year project, entitled School Libraries on the Agenda, is funded by IFLA and is being managed by the Joint Committee of the International Association of School Librarianship (IASL) and the School Libraries Section of IFLA. The final project will include a variety of materials: a trainer's manual, workshop plans, case studies, and video clips.
\end{abstract}

Keywords: Advocacy, leadership, online education, professional development

\section{Overview of the School Libraries on the Agenda Project}

In October 2011, the Joint Committee of the IFLA School Libraries Section and the IASL submitted a proposal to the Professional Committee of IFLA for a two-year funded project to develop school library advocacy materials that would contribute to IFLA's Building Stronger Library Associations initiative and to IFLA's Online Learning Platform. The proposal was in line with the ideas presented by then-president of IFLA Ellen Tise at a meeting of the Joint Committee at the IASL conference in Kingston, Jamaica in August 2011.

The goals and objectives of the project were: (1) to develop a module of training materials for school library advocacy, including association development, communication skills, professional development design, and collaboration and advocacy skills; and (2) to disseminate these through IFLA's Online Learning Platform.

The project was designed to contribute to IFLA's strategies for building stronger library associations in two ways: (1) to contribute to improving school libraries (IFLA Strategy: "Empowering libraries to enable their user communities to have equitable access to information"); and (2) to develop the leadership skills of those involved in school library development (IFLA Strategy: "Building the strategic capacity of IFLA and that of its members"). These are strategies that align with the goals and objectives of IASL as well.

Early in 2013, the Joint Committee was informed that the two-year project had been approved for funding by the IFLA Professional Committee under the Building Strong Library Associations (BSLA) program. The Joint Committee was awarded 850 euros to support the first year's work, to be undertaken in 2012, to develop an online training module for school 
library advocacy. Randy Lundvall, Chair of the IFLA School Libraries Sector took on the responsibility of manager for the project. This included reporting to the IFLA Professional Committee on the progress of the project and applying for the funding for year two of the project.

The proposed project included providing opportunities for presenting draft materials to the international school library community, obtaining feedback on the materials, and consulting regularly with the executives of the two international school library groups and with IFLA staff. Members of the Joint Committee met with Fiona Bradley and Joanne Yeomans from IFLA staff in August 2012 at the Helsinki IFLA conference. A workshop on School Libraries on the Agenda was held November 2012 at the IASL conference in Doha, Qatar (reported later in this paper). Future workshops include a one-day satellite conference on school library advocacy in Kuala Lumpur, Malaysia on August 24, 2013 and a three-hour workshop in Bali at the IASL conference on August 26, 2013. Testing the materials in an online workshop with IFLA / IASL members is an important last step in validating the School Libraries on the Agenda Module before adding it to IFLA's Online Learning Platform.

\section{Formation and Membership of the Joint Committee}

The idea of a joint committee of the two international school library groups had been discussed repeatedly over the 40-year history of the two groups. The current joint committee was an initiative of James Henri of Australia in the early 2000s. He had served on the executives of both international school library groups, and he saw the need for the two groups to unite their school library advocacy efforts. Lourense Das facilitated the contact between the two groups, since she had been involved with both groups for a long time and she lived closest to the IFLA headquarters in The Hague. Formal discussions about how the two school library groups might work together took place at the 2006 IASL conference in Lisbon, Portugal. The IFLA secretary at the time, Sjoerd Koopman, travelled to Lisbon especially for the meeting. At the meeting the collaboration was outlined and later formalized into a memorandum of agreement. That agreement was reviewed and renewed in 2009 and in 2012.

By 2011, the IASL-IFLA Joint Committee had developed a strong history of successful collaborative work. For example, it had sponsored two satellite conferences (Reading in the Digital Age in 2009 in Italy and School Libraries: Best Practices for e-Learning in 2011 in Jamaica) and had developed the content for the book Global Perspectives on School Libraries: Projects and Practices (IFLA publication, no. 148, 2011, co-edited by Luisa Marquardt and Dianne Oberg).

As of July 2011, the members of the Joint Committee were Dianne Oberg (Canada, Chair), Randi Lundvall (Norway), Diljit Singh (Malaysia), Lourense Das (Netherlands), Luisa Marquardt (Italy), and Lesley Farmer (USA). In April 2012, because of the demands of the school library advocacy project, two new members were added to the Joint Committee: Jeff Yasimchuk from Canada (VP-Advocacy, British Columbia Teacher-Librarian Association) and Barbara Schultz-Jones from the USA (Secretary, IFLA School Libraries Section).

\section{Initiating the School Libraries on the Agenda Project}

Members of the committee started the project by collecting and analyzing school library advocacy materials, primarily materials available in English, including those developed by school library associations in the UK, Australia, USA, Canada and elsewhere. They also reviewed the library advocacy modules that had already been developed and posted on IFLA's Online Learning Platform.

Plans began almost immediately to identify potential writers for school library advocacy case studies and to develop other draft materials for piloting in a face-to-face workshop in conjunction with the IASL conference in Doha, Qatar in November 2012. 


\section{Developing the School Libraries on the Agenda Materials}

The Joint Committee has used a variety of communication media in its work: a blog; a wiki; a virtual meeting space on Tapped In; Skype conversations; phone calls; and emails. Lesley Farmer wrote the first draft of the trainer's manual and related resources. Writers have agreed to serve as lead writers for case studies about school library advocacy work in various parts of the world: Canada (Jeff Hasinchuk), Norway (Siri Ingvaldsson), Sweden (Helle Barrett), ENSIL-Europe (Lourense Das), and Indonesia (Diljit Singh). The ENSIL, Norway and Sweden case studies have been completed. Discussions are ongoing about creating some multimedia resources for the module and for using the module as an online short course. Testing the School Libraries on the Agenda module in an online workshop with IFLA / IASL members, as mentioned earlier, is an important final step before adding it to the Online Learning Platform. The three completed case studies should be posted on the Online Learning Platform soon; they have already been posted on the blog for the project.

\section{Sharing the Project at the IASL 2012 Conference}

A workshop on the School Libraries on the Agenda project was presented at the IASL 2012 Conference, "The Shifting Sands of School Librarianship," in Doha, Qatar. This workshop gave the committee an opportunity to pilot draft materials and to get feedback from the workshop participants on the draft materials.

\section{Summary of Workshop}

Approximately 35 participants attended the School Libraries on the Agenda workshop presented by three members of the Joint Committee of IASL / IFLA SLRC: Dianne Oberg (Chair) from Canada; Luisa Marquardt from Italy; and Barbara Schultz-Jones from the USA. Participants received a handout including the workshop slides, the case study Making a Difference, and descriptions of the BSLA modules and case studies. They also received a USB drive loaded with school library advocacy materials including the UNESCO/IFLA School Library Manifesto, IFLA School Library Guidelines, and the draft Trainer's Manual for the School Libraries on the Agenda module.

Dianne Oberg gave an overview of IFLA's program for Building Strong Library Associations (BSLA) and explained that the School Libraries on the Agenda, which is being developed as a part of BSLA, is a joint project of two international school library groups, IASL and the School Libraries Section of IFLA. She also explained that the goal of the project is to develop online advocacy materials specific to the school library sector and that the project is being funded for two years by the Professional Committee of IFLA.

Barbara Schultz-Jones then led an activity focused on school library advocacy values/goals. She pointed out that the two international groups working on the project have shared values, values that participants as individuals and as association members also share.

Dianne Oberg then led the group through Making a Difference, a case study about the advocacy work of a teacher-librarian in Australia. She reminded the participants that case studies are an important way of expanding our learning and our practices through exploring the experiences of others.

Because the participants had chosen this particular workshop, we expected that they would be interested in learning how to be more effective advocates for school libraries. Barbara presented some ways in which participants might work as advocates.

Luisa Marquardt presented a second case study, telling the story of how the associations and individuals involved in the school library advocacy program in Italy were challenged to shift into lobbying activities when the Ministry of Education issued a decree eliminating 
school library positions. This remains an ongoing situation-the decree has been suspended, but this may be challenged again after the upcoming national elections.

At the end of the workshop, participants completed the feedback form and were invited to provide their contact information if they wished to be updated on the work of the School Libraries on the Agenda project.

\section{Summary of Feedback}

As promised in the PC proposal for the project, the workshop participants were asked for feedback on the draft materials for School Libraries on the Agenda project. Of the 23 participants who submitted feedback forms, 9 were aware of the BSLA program prior to attending the workshop. Just over half of these had heard about BSLA from IFLA members. Considerable interest in receiving updates on the School Libraries on the Agenda project was evident: at the end of the workshop, 18 participants requested to be updated on the progress of the project.

The case studies were most frequently mentioned as useful sources of advocacy information (e.g., being able to see how others deal with problems). Building networks and networking were also frequently mentioned as valuable for advocacy purposes.

Viewed together, the responses to the questions about information/materials that should be added to the module and about "takeaways" from the workshop suggest some considerations for future development of the School Libraries on the Agenda materials: incorporate more information from IFLA's School Library Manifesto and School Library Guidelines (e.g., mission, standards, roles) and enhance development of materials to support the long-range planning of advocacy programs and the targeting of specific stakeholder groups.

The participants could foresee using the BSLA materials for offering local workshops (34 checks), for individual study (28 checks), and for online courses (20 checks). Four participants saw the materials as useful in library education. The participants' preferred communication media were listservs (13 checks) and Facebook (11 checks).

The workshop presenters observed that interest in the School Libraries on the Agenda workshop was likely increased by an earlier conference presentation by Ann Ewbank (Arizona State University), entitled "School Library Advocacy Literature in the United States: A Content Analysis." Dr. Ewbank attended the School Libraries on the Agenda workshop and has committed to working with the Joint Committee on the project.

\section{Sharing the Project at the IFLA / IASL Satellite Conference}

Getting school libraries on the agenda of a school staff, a community of educators, a ministry of education, or a library association is often a challenge. The morning session of this fullday workshop on Saturday, August 24, 2013 in Kuala Lumpur, facilitated by IASL President Diljit Singh, will begin with the status reports (successes and challenges) related to school libraries in various countries. The IFLA School Library Manifesto will be discussed in relation to the role of school libraries, and IASL Vice-president Lesley Farmer will present insights via the Internet on the present and future role of school libraries. Advocacy tools and techniques, including those from the School Libraries on the Agenda module, will be presented by Joint Committee Chair Dianne Oberg.

The afternoon session of the workshop will focus on developing advocacy plans, facilitated by Joint Committee members Barbara Schultz-Jones and Lourense Das.

Participants will work in small groups to develop advocacy plans for an institution / school, region/state/province, or nation, or even at international level, using the School Libraries on the Agenda module plus any other resources they may have, and the knowledge gained in 
the morning. At the end of the working session, each group will present their advocacy plan, briefly, using a single PowerPoint slide. The day will conclude with a wrap-up summary and participant feedback. Advocacy materials on USB drives will be a "takeaway" for all workshop participants.

\section{Sharing the Project at the 2013 IASL Conference}

The School Libraries on the Agenda workshop will be presented in Bali by three members of the Joint Committee: Dianne Oberg (Chair) from Canada; Lourense Das from the Netherlands; and Barbara Schultz-Jones from the USA. This three-hour workshop is designed for school library practitioners as well as for school library association and leaders.

The first part of this three-hour workshop will provide a summary of the work of the Joint Committee of IASL and IFLA's Section of School Libraries and Resource Centers (SLRC) in developing advocacy materials. Highlights of the Kuala Lumpur satellite conference will also be presented. At the end of the workshop, upon completing a brief feedback survey, participants will receive a flash drive containing materials that they may adapt and use in their own advocacy work.

The second part of the workshop will focus on planning an advocacy program. Participants will be introduced to an advocacy planning template and then work in small groups to draft a plan for an advocacy program. Participants will share their ideas with others in the workshop and discuss ways in which an advocacy program might be planned and implemented in their local or national context.

\section{Future Plans for School Libraries on the Agenda}

Work remains to be done to complete the project by December 2013:

- Processing the evaluation forms from the Kuala Lumpur and Bali workshops

- Revision of the trainer's manual to incorporate suggestions from workshop participants

- Completion of two more case studies, on collecting data for advocacy purposes (Canada) and on establishing a new school school library association (Indonesia)

- Creation of multimedia resources for the module (likely video clips)

- Testing the School Libraries on the Agenda module in an online workshop with IFLA / IASL members

- Possibly, arranging to use the module as an online short course

- Creating an online tool, perhaps based on the current bog for School Libraries on the Agenda, for participants to ask questions and to share theiur experiences and ideas

- Providing resources on school library advocacy (e.g., reference lists, blogs, websites) for the websites of IASL and IFLA School Libraries

- Translation of the module into other official languages of IFLA

School Libraries on the Agenda has proven to be an ambitious project, one that has tested the mettle of the members of the Joint Committee, all of whom carry responsibilities for executive roles in local, national, and/or international school library associations as well as their personal and professional responsibilities. Despite the challenges, our commitment to placing school libraries on everyone's agenda remains unwavering as we continue to advocate the value of the school library's contribution to student achievement.

\section{Sources Consulted}

Barrett, H., \& Eriksson, B. (2013). A government mandate for school libraries in Sweden [BSLA case study]. Retrieved from http://schoollibrariesontheagenda.wordpress.com/ 
Das, L. (2013). Collaborative networks supporting advocacy [BSLA case study]. Retrieved from http://schoollibrariesontheagenda.wordpress.com/

Ewbank, A., \& Kwon, J. (2013). School library advocacy literature in the United States: A content analysis. Retrieved from http://schoollibrariesontheagenda.wordpress.com/

Ingvaldsen, S. (2013). A school library promotion campaign in Norway [BSLA case study]. Retrieved from http://schoollibrariesontheagenda.wordpress.com/

Marquardt, L., \& Oberg, D. (Eds.). (2011). Global perspectives on school libraries: Projects and practices. IFLA publication, no. 148. The Hague, Netherlands: DeGruyter Saur.

Oberg, D. (2013, June). Joint Committee of IASL / IFLA School Libraries Section. IASL Newsletter, 42(2), 2-3.

School Libraries on the Agenda blog. Retrieved from http://schoollibrariesontheagenda.wordpress.com/

\section{Biographical note}

Dianne Oberg (Canada), PhD, Chair, Joint Committee of IASL/IFLA School Libraries Section. Dianne is a Professor Emerita in school library education at the University of Alberta (Teacher-Librarianship by Distance Learning program). Previously, she was a classroom teacher and teacher-librarian. Her research focuses on school library program implementation and evaluation. Her publications include Focus on Inquiry: A Teacher's Guide to Implementing Inquiry-based Learning (2004), co-authored with Jennifer Branch, and an IFLA/IASL publication, Global Perspectives on School Libraries: Projects and Practices (2011), co-edited with Luisa Marquardt.

Barbara Schultz-Jones (USA), PhD, is an Associate Professor and the Director of the School Library Program in the College of Information at the University of North Texas. Her research interests include the school library learning environment and the organization of information. She is an active member of ALA, AASL, IASL, and IFLA. She also leads study abroad projects setting up library automation systems in school libraries, including automation projects in Thailand, Albania, Ukraine, Peru and Russia. Visit her Web site at: http://courses.unt.edu/bjones/index.htm.

Lourense H. Das (Netherlands), BA in Library Sciences, specialization school libraries. Lourense has worked in various schools and educational libraries and founded Meles Meles SMD, a private consultancy company in 1996. She has worked as executive officer for the Dutch School Library Association (LWSVO) and the Dutch Library Association (NVB). In 2009, she won the National Education Fair Innovation Award for FacTotem 2.0 and was nominated for the SME Limburg Innovation Award. Lourense's international work includes secretary of the IFLA SLRC (2005-2007); coordinator and chair of ENSIL (since 2003); Director Europe (2003-2009) and VP Association Operations for IASL (since 2010). 